\title{
USE OF NON-TRADITIONAL VEGETABLE RAW MATERIALS IN THE TECHNOLOGY OF FLOURY CONFECTIONARY PRODUCTS FOR RESTAURANT ECONOMY ENTERPRISES
}

\author{
Yuliya Myroshnyk \\ yuliyamyro@gmail.com \\ Viktor Dotsenko ${ }^{1}$ \\ dotsvf@gmail.com \\ Larisa Sharan \\ larisharan@ukr.net \\ Vita Tsyrulnikova \\ vita-niki@ukr.net \\ ${ }^{1}$ Department of Hotel and Restaurant Business \\ National University of Food Technologies \\ 68 Volodymyrska str., Kyiv, Ukraine, 01601
}

\begin{abstract}
Products of biscuit dough are ones of most popular among floury confectionary products that is conditioned by their taste advantages, and ones of constant elements of food rations. Biscuit semi-products are a base of such confectionary products as tarts, fancy cakes, cookies.

It is expedient to use supplements of non-traditional raw materials that can not only influence the technological process and quality of ready products, but also enrich them with biologically active substances as additional components of floury confectionary products. The most promising raw material for enriching products of this group is vegetable powders, because fresh products are seasonal and don't regularly provide the food ration of the population with biologically active substances.

The article considers a possibility of using snowball, ashberry and buckthorn powders for making biscuit semi-products. The aim of the work was to study the expedience and technological possibility of using vegetable raw materials in the biscuit semi-product technology.

The chemical composition of chosen powders was studied. The influence of vegetable powder on the quality and quantity of cellulose, structural-mechanical and physical properties of dough was established. The expedience of using surface-active substances in the biscuit semi-product technology for improving the quality of ready products was substantiated.

Keywords: floury confectionary products, biscuit semi-product, vegetable powders, improvers, non-traditional vegetable raw materials.
\end{abstract}

\section{Introduction}

Under modern conditions of economic activity an essential part of restaurant economy enterprises (REE) offer visitors floury confectionary products (FCP), produced by themselves. FCP are of the wide demand among the population and REE visitors. At that their chemical composition is unbalanced by main nutrients and characterized by the high content of easily assimilated carbohydrates and fats. Determining the chemical composition of FCP purposefully, we can effectively influence the food ration of a person, his/her health status, labor activity and so on.

Near $25 \%$ in the total volume of produced FCP belong to ones of biscuit dough. Biscuit products are remarkable for easy assimilability, pleasant taste and smell, pleasant outlook. Well baked biscuit is suitable for processing, has a thin even surface crust; porous elastic crumble struc- 
ture - is easily compressed at pressing, renews an initial form after removing an effort. A wide assortment of tarts, fancy cakes, rolls is produced, based on biscuit semi-products.

Main tasks, set for own production, are connected with a necessity to widen the assortment of FCP, prolongation of their storage term, increase of their food value at the expanse of using new non-traditional raw materials. Non-traditional vegetable raw materials have a wide spectrum of functional properties that allow to influence ones of products, course of the technological process, to regulate properties of structural components of raw materials in the given direction, to improve physical-chemical and organoleptic characteristics of semi-products and ready products, to improve their quality indices, food value and to correct their chemical composition.

\section{Literature review}

Powders of non-traditional vegetable raw materials are promising for enriching FCP. Fresh products are seasonal and don't regularly supply the food ration of the population with biologically active substances. At drying moisture is released from vegetable objects, concentration of substances in cellular juice and its osmotic pressure increase that prevents the development of microorganisms. The chemical concentration of dried berries is concentrated and high-energetic, rich in carbohydrates, pectin and mineral substances, vitamins and organic acids [1].

Apple powder became widely used in food technologies. Its food value is in the content of vitamins and microelements, able to be stored for up to two years.

Studies as to the possibility of using apple powder in the caramel technology are conducted. It has been established, that adding apple powder at producing caramel allows to increase the food value of a ready product at the expanse of pectin and mineral substances, to exclude synthetic aromatic, flavoring and coloring substances from the recipe [2]. Technologies of using apple powder for producing fruit biscuits, gingerbread and decorating semi-products are substantiated and developed. The authors have established that adding apple powder to biscuits, cookies and gingerbread in amount $10 \ldots 15 \%$ allows to get high-quality ready products, to prolong storage terms of products, to increase their biological value [3-5].

There is substantiated a possibility of using $10 \%$ of persimmon powder instead of wheat flour in the technology of sandy products that improves structural parameters of sandy cookies, increases their biological value and at the same time results in decreasing the energetic value of the product [6].

The introduction of pumpkin powder to the recipe of biscuits in amount $5 \ldots 15 \%$ of the flour mass favors the improvement of their food value due to the pumpkin biochemical composition. The great amount of easily assimilated sugars, pectin, iron, cooper, cobalt, zinc, fluorine actively influence the blood circulation, increases the immunity, remove hard metals and radionuclides from the organism [7].

The addition of blackberry powder in the technology of biscuit semi-products allows to get products with an increased content of biologically active substances, especially antioxidants, fatty acids and minerals [8].

A possibility of getting waffle leaves, enriched with girasol powder, is studied [9]. It has been established, that girasol powder decreases the dough viscosity and increase the waffle brittleness.

Analyzing the literary data, a conclusion may be made that vegetable powders are promising raw materials for using in the FCP technology.

\section{Aim and tasks}

The aim of the work was to study the possibility of using vegetable raw materials of snowball, ashberry and sea buckthorn in the biscuit semi-product technology.

The following tasks were set for attaining this aim:

- to study the chemical composition of snowball, ashberry and sea buckthorn powders;

- to establish an influence of adding the selected vegetable powders on the quality and quantity of dough cellulose;

- to determine an influence of the vegetable powders on firm-elastic properties of dough. 


\section{Materials and methods}

The content of total protein in vegetable powders was determined by the standard Kjeldahl method. The determination of the amino acid composition of vegetable powders was conducted by the method of ion-exchanging liquid-column chromatography, using the automatic amino acid analyzer T 339 (Czechia) [10].

The content of ash in the vegetable powders was determined by burning a batch of a studied sample with burning a mineral through in the muffle stove at temperature $450 \ldots .500{ }^{\circ} \mathrm{C}$. The content of separate mineral elements was established by the method of X-ray fluorescent analysis (RFA), using the spectrometer of X-raying energy ElvaX. RFA method is based on measuring energy (wave length in spectrometers with wave dispersion) and intensity of spectral lines, imitated at secondary $\mathrm{x}$-ray emission. The initial flow of quanta from the $\mathrm{x}$-ray tube irradiates a sample, in such a way making each element of this sample to emit secondary x-ray quanta. They have a set of energies (base for the quality determination of the composition), inherent to this element only, and flow intensity of the secondary emission, depending on the content of this element in a sample (base for quantity analysis). Spectrums of x-ray fluorescence are connected with electronic passages in internal levels of an atom that makes them insensitive to chemical connections.

The content of cellulose in flour and its quality was determined by the standard method according to SS 27839-88, elasticity of cellulose - on the device IDC-1 by the standard method.

Physical characteristics of dough samples were determined by the alveographing method on the alveograph Chopin (SSU 4111.4-2002). Rheological properties of dough of wheat flour were determined by the analysis of farinograms, obtained on Brabender farinograph (SSU 4111.1-2002).

Rheological properties of the experimental samples were studied on «RHEOMETER AX-2000». The rheometer allows to determine the main rheological parameter - effective viscosity of an experimental sample that is a non-Newtonian liquid. The measurements were conducted immediately after dough mixing at the room temperature.

The porosity of ready products was determined on the device by Zhuravlev by the standard method.

\section{Results}

It is offered to use fruit powders (TC U 15.3-23913766-002:2005), namely ashberry (PA), snowball (PS) and sea buckthorm (PB) as non-traditional vegetable raw materials in the technology of biscuit semi-products. Based on analytic reviews [11-13] and obtained experimental data, there was studied the chemical composition of vegetable powders. A control was chosen as wheat flour of the highest sort, the main recipe component of floury confectionary products. The chemical composition is presented in Table 1.

Table 1

Chemical composition of powders of ashberry, snowball, sea buckthorn and wheat flour of the highest sort

\begin{tabular}{lcccc}
\hline \multirow{2}{*}{$\begin{array}{c}\text { Main components, } \\
\text { g/100 g }\end{array}$} & \multicolumn{4}{c}{ Studied raw material } \\
\cline { 2 - 5 } & Wheat flour h/s & PA & PS & PB \\
\hline Proteins & 10.3 & 5.9 & 4.7 & 6.8 \\
Fats & 1.1 & 2.9 & 0.3 & 4.1 \\
Carbohydrates & 73.6 & 81.2 & 86 & 79.1 \\
- Mono and & 1.6 & 16.7 & 16.9 & 19.1 \\
disaccharides & 68.5 & 0.4 & 0.2 & 0.3 \\
- Starch & 3.5 & 23.2 & 21.3 & 25.0 \\
- Dietary fiber & 0.5 & 3.2 & 1.9 & 2.5 \\
- Ash & - & 5.6 & 11.8 & 9.7
\end{tabular}


The research results (Table 1) demonstrate that the chosen powders are inferior to wheat flour by the protein content in 1.5...2.2 times. By the fat content PA exceeds wheat flour in 2.6 times, PB - in 3.7 times. At that PS contains only traces of fats. At the same time the content of mono- and disaccharides in PA, PS and PB exceeds their content in wheat flour in 10.4, 10.6 and 11.9 times respectively. The content of dietary fiber - in 6.6, 6,1 and 7.1 times respectively that allows to use them as a source of essential ingredients.

As far as vegetable powders contain the essential content of proteins, a decision was made to conduct a research for determining their amino acid composition and comparing analysis with one of wheat flour. The results are presented in Table 2.

\section{Table 2}

The amino acid composition of proteins of powders of ashberry, snowball, sea buckthorn and ones of wheat flour of the highest sort

\begin{tabular}{ccccc}
\hline Amino acids, $\mathbf{m g} / \mathbf{g}$ & Wheat flour h/s & PA & PS & PB \\
\hline Alanine & 0.077 & 1.77 & 2.70 & 3.69 \\
Arginine & 0.075 & 1.79 & 3.18 & 19.85 \\
Aminosuccinic acid & 0.171 & 5.13 & 6.57 & 5.01 \\
Valine & 0.04 & 1.96 & 3.14 & 3.38 \\
Histidine & 0.009 & 0.31 & 0.24 & 14.29 \\
Glycine & 0.024 & 2.94 & 3.62 & 36.75 \\
Glutamic acid & 0.098 & 8.62 & 11.19 & 3.54 \\
Isoleucine & 0.028 & 0.45 & 0.61 & 9.46 \\
Leucine & 0.083 & 2.13 & 3.19 & 8.52 \\
Lysine & 0.023 & 1.14 & 1.98 & 1.81 \\
Methionine & 0.017 & 0.28 & 0.57 & 11.50 \\
Proline & - & 5.40 & 7.21 & 9.84 \\
Serine & 0.203 & 1.44 & 3.08 & 4.88 \\
Tyrosine & 0.032 & 0.79 & 1.34 & 5.38 \\
Threonine & 0.138 & 1.00 & 1.95 & 5.71 \\
Phenylalanine & 0.067 & 0.93 & 0.87 &
\end{tabular}

Analyzing the data of Table 2, a conclusion may be made that proteins of vegetable raw material powders exceed ones of wheat flour of the highest sort by the content of amino acids in $30 . .400$ times. At that the part of irreplaceable and conditionally irreplaceable amino acids in PA is more than $27 \%$, PS - $31 \%$, PB - $36 \%$, that indicates their high biological value. Proteins of the studied powders contain the essential amount of such amino acids as glycine, aminosuccinic and glutamic acids. Thus, PA, PS and PB contain in 123, 151 and 595 times more glycine than proteins of wheat flour, aminosuccinic acid - in 30, 38115 times, glutamic acid - in 88, 114 and 375 times respectively. Proteins of PA, PS and PB contain the essential amount of proline that is absent at all in ones of wheat flour of the highest sort and arginine that is an irreplaceable amino acid for children.

For confirming the expedience and possibility of using powders of dried berries of wild raw materials as supplements, enriching floury confectionary products with vitally important nutrients, there was determined a mass share of vitamins and mineral substances of powders, comparing with the composition of wheat flour of the highest sort. The obtained data are presented in Table 3. 
Table 3

The content of vitamins and mineral substances in the studied vegetable powders and wheat flour of the highest sort

\begin{tabular}{|c|c|c|c|c|}
\hline $\begin{array}{c}\text { Main components, } \\
\mathrm{mg} / 100 \mathrm{~g}\end{array}$ & Wheat flour $\mathrm{h} / \mathrm{s}$ & PA & PS & PB \\
\hline \multicolumn{5}{|c|}{ Vitamins } \\
\hline Ascorbic acid (vitamin C) & - & 66.1 & 34.7 & 68.6 \\
\hline$\beta$-carotene & - & 16.6 & 4.5 & 8.2 \\
\hline Tocopherol (vitamin E) & 2.45 & 11.6 & 2 & 90.6 \\
\hline \multicolumn{5}{|l|}{ P-active: } \\
\hline Flavonols & - & 88.1 & 95.2 & 111.9 \\
\hline Catechins & - & 48.7 & 447.9 & 53.0 \\
\hline Anthocyans & - & 103.2 & 947.0 & 250.0 \\
\hline \multicolumn{5}{|c|}{ Macroelements } \\
\hline Calcium & 18.0 & 390 & 167.2 & 107 \\
\hline Potassium & 122.0 & 625.3 & 921.3 & 1341 \\
\hline Magnesium & 16.0 & 114.4 & 62.9 & 102.6 \\
\hline Phosphorus & 86.0 & 183 & 96.7 & 46.1 \\
\hline Sodium & 3.0 & 12.8 & 21.5 & 17.5 \\
\hline \multicolumn{5}{|c|}{ Microelements } \\
\hline Iron & 1.2 & 8.0 & 4.72 & 10.4 \\
\hline Manganese & 0.57 & 11.5 & 0.2 & 0.93 \\
\hline
\end{tabular}

Having analyzed the chemical composition of PA, PS and PB and wheat flour, a conclusion may be made that these vegetable raw materials can be an effective improver of FCP with biologically active substances (BAS), especially $\beta$-carotene, vitamins E, C, P mineral substances and micro/macroelements (Ca, Mg, K, P, Na, Fe, Mn).

PA, PS and PB have the improved vitamin composition, comparing with wheat flour. At that PA exceeds wheat flour in almost 5 times by the content of vitamin E, and PB - in 36 times by the content of vitamin $\mathrm{C}$ and $\mathrm{P}$. Thus, analyzing the obtained data, a conclusion may be made that the studied vegetable powders have the rather high content of polyphenol substances and beta-carotene, tocopherol that give them antioxidant properties.

Comparing with wheat four of the highest sort, the studied raw materials contain more calcium in $6 \ldots 22$ times, potassium in $5 \ldots 11$ times, magnesium in $4 \ldots 7$ times, sodium in $4 \ldots 7$ times, iron in 4 ...8 times. PA contains 2 times more phosphorus than wheat flour and 20 times more magnesium.

Thus, PA, PS and PB contain much more micro and macroelements, comparing with wheat flour of the highest sort. It allows to enrich FCP, especially biscuit semi-products, with essential nutrients.

At the research there was determined an influence of PA, PS and PB on the quality and quantity of cellulose, namely elasticity, extensibility and ability to hydration. Quality parameters of cellulose directly depend on the content and properties of dough recipe components. As far as vegetable powders are able to intermolecular connections with other biscuit dough ingredients, their influence on wheat flour cellulose was studied. At studying the influence on cellulose, wheat flour was added with 3, 6 and $9 \%$ of the studied supplements to the flour mass. The influence of the vegetable powders on the cellulose quantity (Fig. 1) and its quality was determined for each dosage. Wheat flour without supplements was used as a control.

As it can be seen from the obtained data, a tendency to the cellulose content decrease was established in the whole diapason of concentrations of the introduced powders. The amount decrease of wet cellulose with the mass share increase of powders may be explained by the fact that vegetable 
raw materials bind recipe moisture and prevent proteins swelling. In its turn, it favors their washing out from a flour sample together with starch and other components. It has been established, that cellulose with adding vegetable powders is characterized with higher elasticity parameters. Thus, the extensibility decreases (with PA by $9.7 \ldots 16 \%$, PS - 16...26 \%, PB - by $16 \ldots .35 \%$ with dosage increase) and correspondingly elasticity (with PA by $2 \ldots 4.4 \%$, PS $-11.5 \ldots 18 \%$, PB $-8.6 \ldots 31.5 \%$ with dosage increase) and hydration capacity (with PA by $12.4 \ldots 16 \%$, PS $-8.2 \ldots 18.4 \%$, PA $7 . .15 .7 \%$ with dosage increase). The strengthening of the structural-mechanical properties is probably conditioned by creation of complex compounds of flour proteins with carbohydrates and lipids of the introduced supplements. At that there takes place compression of a "package" of protein molecules as a result of creation of additional ion, sorption, hydrogen and other connections.

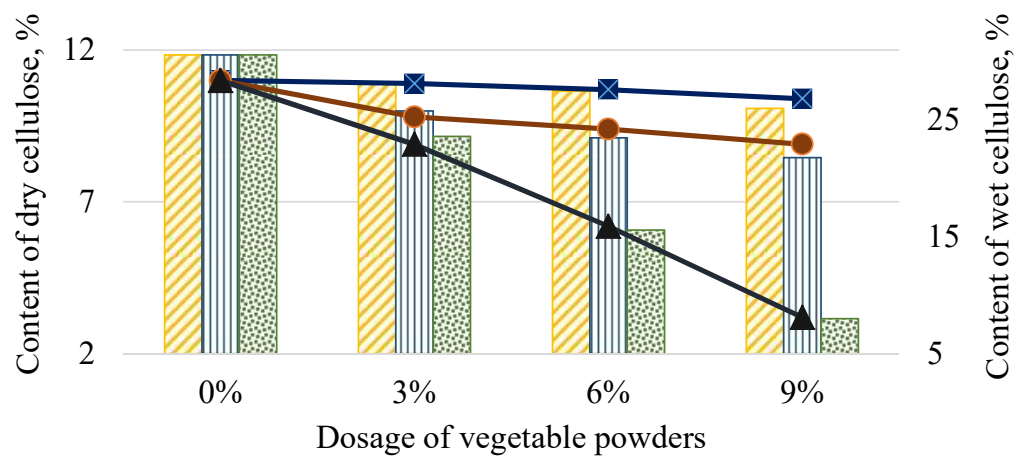

Content of wet cellulose with PA - montent of wet cellulose with PS
Content of wet cellulose with PB $\rightarrow$ Content of dry cellulose with PA
- - Content of dry cellulose with PS - Content of dry cellulose with PB

Fig. 1. Influence of vegetable powders on the amount of dry and wet cellulose

The addition of PA, PS and PB decreases the time of dough creation by $0.5 \mathrm{~min}$. It is probably explained by the amount decrease of cellulose in the mixture and so, its hydration capacity. It has been established, that the addition of the studied powders results in the essential increase of dough dilution, comparing with the control (with PA by $233 \ldots 283 \%$, PS - 233...333 \%, $\mathrm{PB}-233 \ldots 340 \%$ with dosage increase) that is a positive precondition for improving the porosity of ready biscuit semi-products.

The research results of the influence of vegetable powders on the rheological properties of dough have demonstrated that at introducing the supplements the dough elasticity increased (with PA by $29 \ldots 59 \%$, PS - 42...130\%, PB - 95...163\% with dosage increase) and extensibility essentially decreased (with PA by $29.5 \ldots 60 \%$, PS $-31 \ldots 74 \%$, PB $-45 \ldots 80 \%$ with dosage increase).

For verifying the obtained regularities, the experimental baking of biscuit semi-products with the chosen powders in amounts $3 . . .9 \%$ was realized. Analyzing the quality of the ready products, the special attention was paid to their porosity that influences the organoleptic, structural-mechanical and rheological properties of biscuits. The total porosity index was considered as a quantity characteristic of sumptuousness of the products, because the increase of this index testifies to the fact that the volume of products grows and their hardness decreases. At adding $3 \%$ of the fruit powders, the porosity of the ready biscuit semi-products a bit increases by $3-4 \%$. At the dosage increase of PA, PS and PB the porosity decreases correspondingly by $5 \ldots 6 \%, 5.5 \ldots 6.4 \%, 5.7 \ldots 6.6 \%$. It may be explained by more dispersion of fruit powders than wheat flour. Taking into account the obtained data, the desired dosage of PA, PS and PB must be $3 \%$ of the flour mass. But this dosage doesn't provide the needed increase of the products' food value. That is why it is expedient to offer to use SAS for improving the ready products' quality and their food value.

Such SAS of the non-ionogenic effect as propylene glycol monostearate, esters of saccharose, sorbite, polyglycerine and fatty acids and so on are widely used in the confectionary industry. The use of improvers of this group allows to change the rheological properties of dough and favors 
prolongation of the storage term of fresh ready products. SAS are presented at the Ukrainian market by rather wide assortment.

Almost all known producers of SAS for products of biscuit dough offer to introduce them at the stage of shaking mélange with sugar. Such introduction of SAS allows to increase FFC (foam-forming capacity) and foam stability. The system resistance to the mechanical influence makes it possible to introduce additional raw materials, especial ones, containing fat, and as a result, to get products with fluffy crumble and increased specific volume.

We studied the influence of improvers for floury confectionary products, most widespread in Ukraine - Grindsted PGE 55 (Danisco, Denmark), Grindsted cake 100 (Danisco, Denmark) and Ester M03 (EGH ingredients, Ukraine) on the main foam parameter - FFC.

There was determined the FFC of mélange foam, mélange with sugar and mélange with sugar and chosen SAS in the amount according to recommendations of the producers (Grindsted PGE 55 in amount $0.4 \%$, Grindsted cake $100-1 \%$, Ester M03 - $1.5 \%$ ), at temperature $20{ }^{\circ} \mathrm{C}$ (Fig. 2).
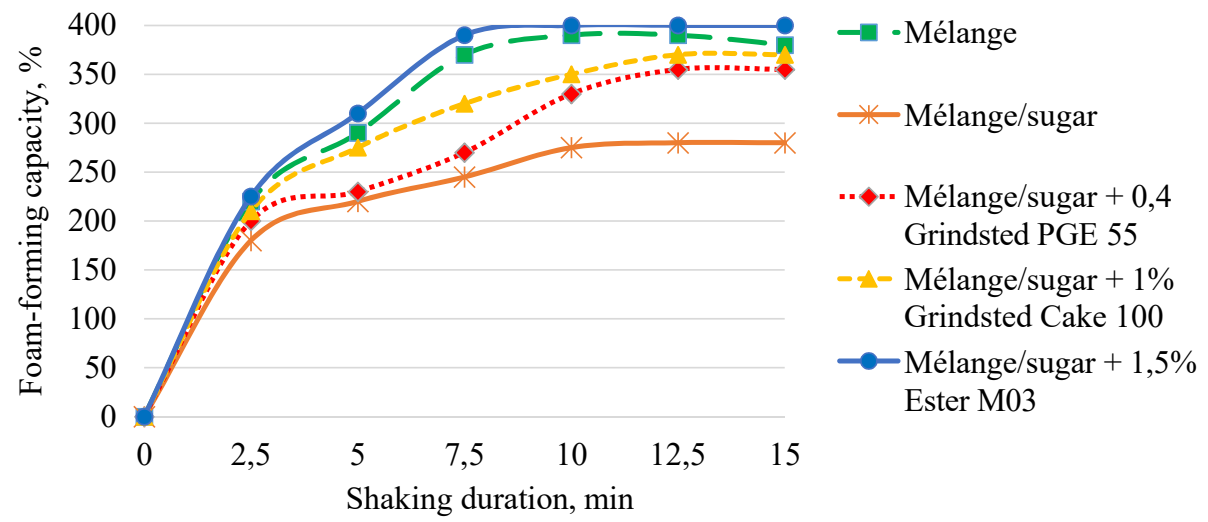

Fig. 2. Kinetics of foam formation of the studied samples

The obtained data have demonstrated that the most value of FFC is inherent to mélange. A sample of mélange with adding sugar has the lowest FFC indices that may be explained by the increase of the surface tension of the liquid phase that complicates its foam formation. At that the increase of the FFC index may be explained by more stable protein structure in sugar solutions, due to which protein molecules are worse untwisted at adsorption at the limit of phase distribution.

Fig. 2. has established that the studied SAS increase the FFC of mélange with adding sugar by $27 . .43 \%$ and decrease the time of mixture shaking in 1.5 times. Especially, the improver Ester M03 has the highest FFC value among the studied samples, namely $400 \%$. That is why it was chosen for further studies in the technology of biscuit semi-products.

The dependence of the shift speed on the tangent tension in biscuit dough is presented on Fig. 3.

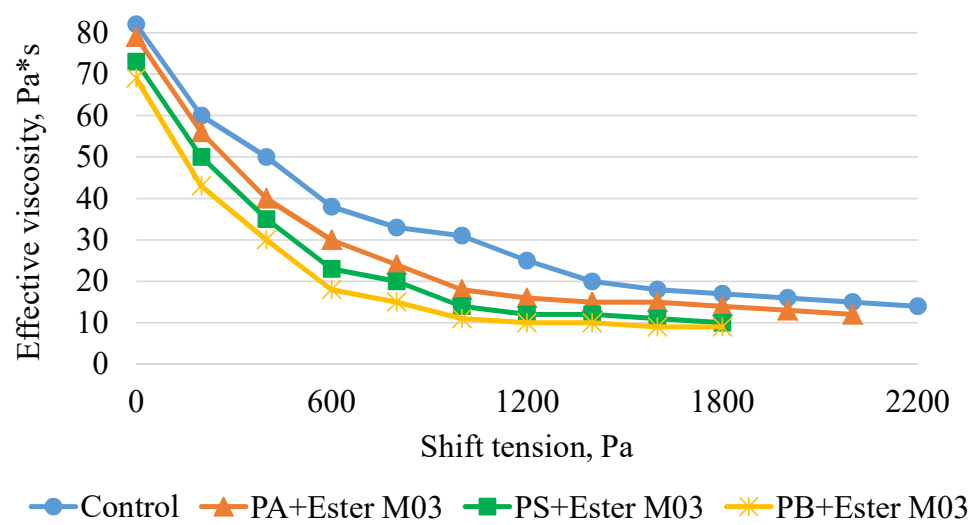

Fig. 3. Rheological curves of viscosity of biscuit dough with vegetable powders and SAS 
The analysis of the presented results has demonstrated that the biscuit dough viscosity decreases with the shift speed increase in both control samples and ones with adding the vegetable powders and SAS. The vegetable powders for the model experiment were added in amount $6 \%$, Ester M03 in amount $1.5 \%$. It has been established, that introduction of the selected powders and SAS results in decreasing the effective viscosity of biscuit dough, comparing with the control sample. The dough viscosity decrease in this case may be noted as a positive effect. As a result of less dough viscosity, air bubbles, included to the dispersed phase, widen more at baking, but a film frame of eggs, sugar, wheat flour and dietary fiber, stronger, comparing with dough without supplements and with ashberry powder, prevents air removal from bubbles outside. A biscuit semi-product at baking settles down less and is characterized by more values of specific volume and porosity that is confirmed by epy physical-chemical parameters of baked products.

The porosity of ready biscuit semi-products with PA, PS and PB and improver Ester M03 increases, comparing with ones with vegetable powders and without SAS correspondingly by $6 . .10 \%$.

\section{Conclusions}

It has been established, that the dosage increase of vegetable powders results in strengthening cellulose, it becomes more elastic and has better extensibility. The strengthening of structural-mechanical properties of cellulose is, probably, conditioned by creation of complex compounds of flour proteins with carbohydrates and lipids of the introduced supplements and the effect of organic acids of the chosen powders.

The introduction of PA, Ps and PB in amount 3...9\% of the flour mass increases the dough elasticity in $1.2 \ldots 2.5$ times and decreases extensibility in $1.5 \ldots 3$ times, comparing with the control. The obtained data may be explained by the essential amount of polysaccharides in the studied raw materials that don't allow to form an elastic cellulose frame and they increase the dough viscosity.

It has been established, that the dosage increase of PA, PS and PB decreases the porosity of ready biscuit semi-products. That is why for raising the quality of ready products, it is expedient to offer to use quality improvers of biscuit semi-products.

It has been demonstrated, that the use of the improver Ester M03 in amount $1.5 \%$ in semi-products with vegetable powders in the technology of biscuit products decreases the biscuit dough viscosity. At the same time there is observed the positive influence of SAS on the FFC of the egg-sugar mixture, main component of biscuit dough.

The use of powders of non-traditional raw materials in the FCP technology results in increasing the food and biological value of ready products. The use of the studied powders at restaurant economy enterprises is a precondition for widening the FCP assortment in a menu.

In further studies it is expedient to determine an influence of vegetable powders on a freshness preservation degree in products with their addition.

\section{References}

[1] Plotnikova, T. V., Tyapkina, E. V. (2006). Plodovo-yagodnye poroshki v muchnyh izdeliyah. Produkty\&Ingredienty, 2, $20-21$.

[2] Shulga, O., Kamenchuk, T., Shulga, S. (2012). Apple powder in additives to enhance food value caramel. Ukrainian Food Journal, 1 (2), 59-61.

[3] Kalakura, M. M., Ratushenko, A. T., Bublik, G. A. (2016). Improving quality of apple powder confectionery. Technology Audit and Production Reserves, 3 (3 (29)), 12-17. doi: https://doi.org/10.15587/2312-8372.2016.70976

[4] Kohajdováa, Z., Karovičováa, J., Jurasováa, M., Kukurováb, K. (2011). Effect of the addition of commercial apple fibre powder on the baking and sensory properties of cookies. Acta Chimica Slovaca, 4 (2), 88-97.

[5] Alsuhaibani, A. M. A. (2015). Biochemical and biological study of biscuit fortified with apple powder. Middle East Journal of Agriculture Research, 04 (04), 984-990.

[6] Dzyundzya O. V. (2013). Shortcut with the use of powders of persimmon. Sbornik nauchnyh trudov Sworld. Materialy mezhdunarodnoy nauchno-prakticheskoy konferentsii «Modern directions of theoretical and applied researches '2013», 1, 60.

[7] Syrokhman, I. V., Fil, M. I. (2008). Pat. No. 35288 UA. Method for making biscuit half-finished product. No. u200804712; declareted: 11.04.2008; published: 10.09.2008, Bul. No. 17. 
[8] Myroshnyk, Yu. A., Kosakivska, H. S., Dotsenko, V. F., Havrysh, A. V. (2013). Pat. No. 83989 UA. Kompozytsiya dlia vyhotovlennia biskvitnoho napivfabrykatu. u201303613; declareted: 22.03.2013; published: 10.10.2013, Bul. No. 19.

[9] Fillipova, E. V., Krasina, I. B., Navitskaya, D. P. (2012). Uluchshenie strukturnyh harakteristik i obogashchenie poroshkom topinambura vafel'nyh listov. Innovatsionnye napravleniya v pishchevyh tehnologiyah: Materialy 5 Mezhdunarodnoy nauchno-prakticheskoy konferentsii. Pyatigorsk, 332-335.

[10] Kozarenko, T. D. (1975). Ionoobmennaya hromatografiya aminokislot. Novosibirsk: «Nauka», 134.

[11] Obolkina, V. I., Sivniy, I. I. (2011). Ryabina v konditerskih izdeliyah. Produkty\&Ingredienty, 11, 30-31.

[12] Yakovleva, T. P., Filimonova, E. Yu. (2011). Pishchevaya i biologicheskaya tsennost' plodov oblepihi. Pishchevaya promyshlennost', 2, 11-13.

[13] Skurihin, M. M., Tutel'yan, A. A. (2007). Tablitsy himicheskogo sostavai kaloriynosti rossiyskih produktov pitaniya. Moscow: DeLi print, 610 .

\title{
STUDY OF THE INFLUENCE OF MEALS OF WHEAT AND OAT GERMS AND WILD ROSE FRUITS ON THE FERMENTING MICROFLORA ACTIVITY OF RYE-WHEAT DOUGH
}

\author{
Svitlan Oliinyk ${ }^{1}$ \\ svitlana.oliinyk@gmail.com \\ Olga Samokhvalova ${ }^{1}$ \\ sam55ov@gmail.com \\ Nadegda Lapitskaya ${ }^{1}$ \\ nadegda.lapitskaja@gmail.com \\ Zinoviya Kucheruk ${ }^{1}$ \\ kzinoviya2703@gmail.com \\ ${ }^{1}$ Department of Bakery, Confectionary, Pasta and Food Concentrates Technology \\ Kharkiv State University of Food Technology and Trade \\ 333 Klochkivska str., Kharkiv, Ukraine, 61051
}

\footnotetext{
Abstract

The aim of the research was to study an influence of meals of wheat germs (WGM) and oat germs (OGM) in amount $10 \ldots 20 \%$, and also ones of wild rose fruits (WRFM) in amount $2 \ldots 6 \%$ of the total mass of flour on the fermenting microflora of rye-wheat dough; and also to establish an influence of the experimental supplements on main microbiological processes in it.

It has been established, that adding experimental meals favors the activation of bakery yeast. At introducing WGM, OGM and WRFM, its lifting force grows by 16.0-54.0, 6.0-18.0, 10.0-44.0 \% respectively, and zymase and maltase activity - by 16.0-53.3, 6.0-17.7 and 11.1-44.0\% and 18.8-55.0, 6.331 .3 and 7.5-25.0\% respectively. It has been established, that there also takes place the activity increase of lactate bacteria in rye-wheat dough with adding meals of wheat, oat germs and wild rose fruits. It is possible at the expanse of adding an additional nutritive medium with the supplements.

Such action of enriching raw materials on the microflora favors intensification of alcoholic and lactate fermentation that is established by data of acid accumulation and gas formation in rye-wheat dough. The counted indices at introducing WGM, OGM, WRFM increase by 39.0, 27.8, 33.9 \% and 18.2, 13.6, $16.7 \%$ respectively.

Keywords: rye-wheat dough, wheat germ meal, oat germ meal, wild rose fruit meal, lactate bacteria, lifting force, fermenting activity, microbiological processes.
} 